\title{
Susceptibility and residual effect of indoxacarb formulations on major soybean lepidopteran pests
}

\author{
Marina Gomes da Silva Oliveira • Rosana Harumi \\ Serikawa • Fábio Maximiano Andrade da Silva • \\ Odair Aparecido Fernandes (D)
}

Received: 15 March 2020 / Accepted: 13 December 2020 / Published online: 3 January 2021

(C) The Author(s) 2021

\begin{abstract}
Chysodeixis includens and Helicoverpa armigera can negatively impact soybean yield due to defoliation and direct injury on the pods, respectively. Insecticides, such as indoxacarb, are still an important controlling tool to manage these insects. To support Integrated Pest Management (IPM) and Insect Resistance Management (IRM) as well as to reduce product decantation during storage and nozzle clogging in field application, a new indoxacarb formulation (emulsifiable concentrate - EC) was developed to replace the suspension concentrate formulation (SC). The objective of this study was to evaluate the susceptibility and compare the residual effects of two indoxacarb formulations on $C$. includens and H. armigera on soybean. A doseresponse curve and the residual effect from in-field application were obtained using a laboratory strain of both insect pests. Soybean leaflets were collected and dipped into aqueous indoxacarb solutions. The evaluations were performed $96 \mathrm{~h}$ after the infestation to calculate the insect mortality percentage and foliar damage.
\end{abstract}

M. G. da Silva Oliveira

Corteva Agriscience, Barueri, SP 06454-080, Brazil

M. G. da Silva Oliveira • O. A. Fernandes $(\bowtie)$

School of Agricultural and Veterinarian Sciences, São Paulo State University (UNESP), Jaboticabal, SP 14884-900, Brazil

e-mail: odair.fernandes@unesp.br

R. H. Serikawa

Corteva Agriscience, Johnston, IA 50131-7060, USA

F. M. A. da Silva

FMC Agricultural Solutions, Paulínia, SP 13148-080, Brazil
Also, plants were sprayed in the field and leaflets from mid and upper regions of the plants were collected and used to feed third-instar larvae of both species. Results demonstrated that $C$. includens and $H$. armigera are similary sensitive to indoxacarb. The residual activity was up to $1 \mathrm{~h}$ after application for $H$. armigera and up to 3 days for $C$. includens. No difference was observed on this activity between mid and upper regions of the plant. Overall, the enhanced EC formulation is as effective as the SC formulation for the control of both species on soybean.

Keywords Chrysodeixis includens · Helicoverpa armigera $\cdot$ Dose-response curve $\cdot$ Residual activity

\section{Introduction}

The soybean looper Chysodeixis includens (Walker, 1858) (Lepidoptera: Noctuidae) is known as an economically important pest to a wide range of host plants such as cotton, beans, tomatoes, potatoes, peanuts (Herzog 1980, Bueno et al. 2007) and soybean (Moscardi et al. 2012). In Brazil, C. includens was considered a secondary soybean pest for many years and was mainly controlled by naturally occurring parasitoids and entomopathogenic fungi (Sosa-Gómez et al. 2003). However, the occurrence of Asian rust in Brazil increased considerably the use of fungicides in soybean (Garcés-Fiallos 2011). These fungicides affect negatively beneficial fungi (Sosa-Gómez 2005) and were most likely responsible for $C$. includens outbreaks as well as for its status 
change to a major soybean insect pest (Bueno et al. 2007, Santos et al. 2017).

In addition, Helicoverpa armigera (Hübner, 1808) (Lepidoptera: Noctuidae), an invasive species identified in Brazil during the 2012/2013 growing season (Czepak et al. 2013), is also a polyphagous insect pest and feeds on vegetative (leaves) and reproductive (flowers and pods) parts of host plants (Czepak et al. 2013, Specht et al. 2013). Injuries caused by this insect leads to yield losses in various agricultural crops such as tomato, cotton, corn, beans and soybean (Fitt 1989, Romeis and Shanower 1996, Pogue 2004, Moral García 2006). Its control is challenging and resistance of this insect pest to several conventional insecticides including synthetic pyrethroids (Forrester et al. 1993), carbamates (Gunning et al. 1996), organophosphates (Gunning et al. 1997) and spinosad (Wang et al. 2009) have been reported (Fitt and Wilson 2000, Yang et al. 2013).

These two species can cause great impact on soybean yields. Helicoverpa armigera alone was responsible for approximately US\$ 800 million in Brazil and C. includens has become a recurrent problem and is considered a key pest in soybean (Specht et al. 2015). Genetically modified (GM) soybean expressing Bacillus thuringiensis toxic protein is the main pest control strategy and was adopted in ca. 58\% of the soybean area cultivated in Brazil (ISAAA 2017). Despite of the great adoption of this strategy, Integrated Pest Management (IPM) tools need to be enhanced to cope with pests that are not targets of GM plants as well as those present in non-Bt soybean.

The insecticide indoxacarb presents low toxicity to the environment (McCann et al. 2001) and to nontarget organisms when compared to pyrethroids or carbamates (Michaud and Grant 2003). Belonging to the group of oxidiazines (McCann et al. 2001), indoxacarb is composed of a chiral carbon with two enantiomers (-)-R-indoxacarb and (+)-S-indoxacarb. It is a pyrazoline-type sodium channel blocker (IRAC MoA subgroup 22A) with activity on lepidopteran, coleopteran, and hemipteran insect pests (Wing et al. 1998, 2004). Indoxacarb is not systemic (McKinley et al. 2002) and is active by contact and ingestion resulting in paralysis and death (Jones and Bryant 2012). One of the main indoxacarb products used in Brazil is Avaunt ${ }^{\circledR}$ SC (DPX-KN128- suspension concentrate). However, product decantation occurred under storage conditions and nozzle clogging observed during field application could be a limiting factor of its effectiveness and use as a control tool. Trying to improve the indoxacarb efficacy, a new formulation was developed: Avatar ® EC (emulsifiable concentrate). This formulation contains an oil solvent and a surfactant to enhance wetting of leaves. The EC formulation blooms into a white cloudy emulsion when poured into water and disperses with minimal agitation in spray tank containing either hard or soft water. The indoxacarb is completely dissolved with no particles to resuspend (DuPont 2013). To support IPM and Insect Resistance Management (IRM), the objective of this study was to evaluate the susceptibility and compare the residual effects of the new indoxacarb formulations EC in comparison to the SC formulation for the control of $C$. includes and $H$. armigera on soybean.

\section{Material and methods}

Insects

Indoxacarb-susceptible laboratory mass reared strains of $C$. includens and H. armigera were used in all studies. Insect colonies were founded after collection of insects in soybean fields in 2008 and 2013, respectively. The insects were reared under controlled conditions $(25 \pm$ $2{ }^{\circ} \mathrm{C}, 46-47 \% \mathrm{RH}, 12: 12 \mathrm{~h}$ [L: D]) at FMC Research and Technology Center (formerly DuPont do Brasil Research Station), located in Paulínia, SP, Brazil.

Susceptibility of laboratory insect strains to indoxacarb

Commercial insecticide formulations of indoxacarb were used: Avaunt SC® (15\% active ingredient) and Avatar EC® (15\% active ingredient). The two indoxacarb formulations (SC and EC) were compared using dose-response curves to evaluate the susceptibility.

Soybean variety BMX Potencia ${ }^{\circledR}$ (Brasmax Genética Ltd., Passo Fundo, RS, Brazil), insecticide free, was grown under greenhouse conditions. Leaflets were randomly collected from soybean plants and taken to the laboratory to be treated when plants were at V4, i.e., 4th trifoliate stage (Fehr and Caviness 1977). They were dipped into different indoxacarb concentrations $(0.001 ; 0.01 ; 0.1 ; 1 ; 10$; 100 ; and $250 \mu \mathrm{g}$ a.i. $/ \mathrm{ml}$ ) for $10 \mathrm{~s}$. The untreated control was dipped into water. The leaflets were left to 

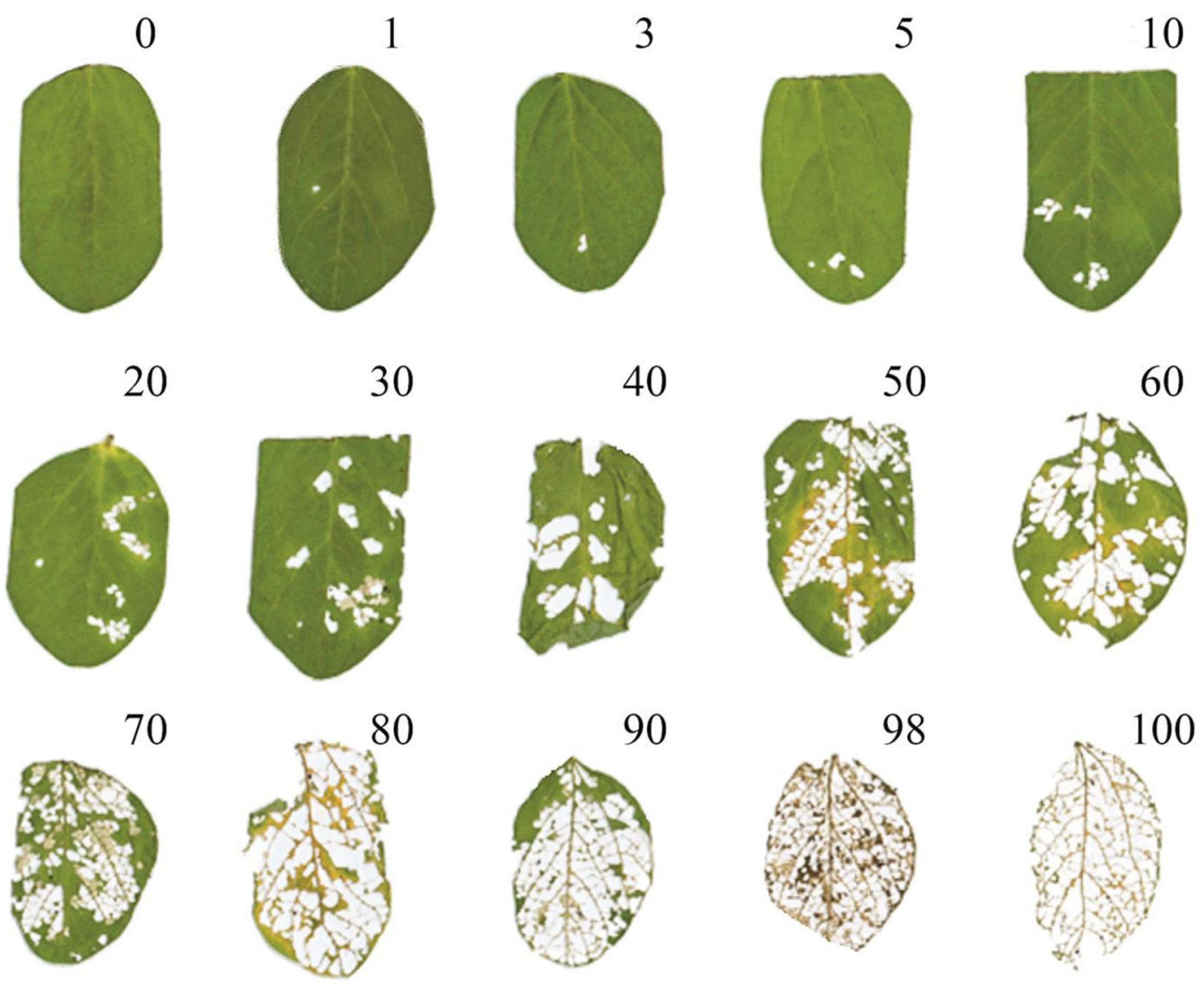

Fig. 1 Defoliation scale used to evaluate injury caused by Chrysodeixis includens and Helicoverpa armigera on soybeans leaflets

air dry at room temperature for approximately one hour. Leaflets were individualized into 16-cell plastic trays (Advento do Brasil, Diadema, SP, Brazil) and a third-instar larvae of $C$. includens was individually introduced (one larva per well and 16 larvae per dose). The same methodology was used for $H$. armigera. The bioassay was carried out under controlled conditions $\left(25 \pm 2{ }^{\circ} \mathrm{C}, 46-47 \% \mathrm{RH}\right.$, $12: 12 \mathrm{~h}[\mathrm{~L}: \mathrm{D}])$ and the evaluations were performed

Table 1 Susceptibility parameters for third-instar larvae of Chrysodeixis includens and Helicoverpa armigera (Lepidoptera: Noctuidae) laboratory susceptible strain tested on soybean leaflets

\begin{tabular}{llllllll}
\hline Species & Insecticide & $\mathrm{N}$ & $\mathrm{LC}_{50}(95 \% \mathrm{FL})$ & $\mathrm{LC}_{99}(95 \% \mathrm{FL})$ & Slope $\pm \mathrm{SE}$ & $\mathrm{Chi}-\mathrm{Square}$ & $P$ \\
\hline C. includens & indoxacarb (15\% EC) & 32 & $0.065(0.028-0.147)$ & $12.969(3.054-186.259)$ & $1.011 \pm 0.157$ & 6.850 & 0.0089 \\
& indoxacarb (15\% SC) & 32 & $0.127(0.046-0.340)$ & $28.055(5.437-762.121)$ & $0.992 \pm 0.174$ & \\
H. armigera & indoxacarb (15\% EC) & 32 & $0.113(0.039-0.314)$ & $46.768(8.234-1352.086)$ & $0.890 \pm 0.148$ & 1.995 \\
& indoxacarb (15\% SC) & 32 & $0.111(0.045-0.277)$ & $31.568(6.430-631.207)$ & $0.948 \pm 0.152$ & 0.1578 \\
\hline
\end{tabular}

$\mathrm{N}$ : number of insects exposed; $\mathrm{LC}_{50}$ and $\mathrm{LC}_{99}$ are the lethal concentration values with $95 \%$ fiducial limits (FL) to kill 50 and $99 \%$ of the larvae exposed; Lethal concentrations are expressed as active ingredient $\left(\mu \mathrm{g} \mathrm{ml}^{-1}\right)$
$96 \mathrm{~h}$ after the infestation. The number of dead, moribund, and alive larvae were registered. A larva was considered dead when there was no movement when softly prodded by a brush or when presented paralysis of the prolegs (Bird 2015). The data were expressed as percentage of mortality. We performed three bioassays for each insect species and product formulation. Each bioassay was considered one replication.

immersed in different insecticide indoxacarb concentrations of formulations EC (emulsifiable suspension) and SC (suspension concentrate) 
Table 2 Mortality $(\% \pm \mathrm{SEM})$ of third-instar Chrysodeixis includens larvae in the upper and middle soybean canopy layers treated with two formulations of indoxacarb (EC - emulsifiable suspension and SC - suspension concentrate)

\begin{tabular}{|c|c|c|c|c|c|}
\hline \multirow{2}{*}{$\begin{array}{l}\text { Canopy } \\
\text { Layer }\end{array}$} & \multirow[t]{2}{*}{ Days after treatment } & \multicolumn{2}{|c|}{ indoxacarb (15\% EC) } & \multicolumn{2}{|c|}{ indoxacarb (15\% SC) } \\
\hline & & $30 \mathrm{~g}$ a.i./ ha & $60 \mathrm{~g}$ a.i./ ha & $30 \mathrm{~g}$ a.i./ ha & $60 \mathrm{~g}$ a.i./ ha \\
\hline \multirow[t]{5}{*}{ Upper } & 0 & $97.50 \pm 2.50 \mathrm{Aa}$ & $98.41 \pm 0.92 \mathrm{Aa}$ & $92.92 \pm 5.16 \mathrm{Aa}$ & $86.62 \pm 11.27 \mathrm{Aa}$ \\
\hline & 3 & $79.29 \pm 6.67 \mathrm{Bab}$ & $93.32 \pm 2.20 \mathrm{Aa}$ & $67.08 \pm 8.59 \mathrm{Bb}$ & $91.16 \pm 4.89 \mathrm{Aa}$ \\
\hline & 7 & $17.07 \pm 7.25 \mathrm{Cc}$ & $44.81 \pm 7.60 \mathrm{Bb}$ & $33.33 \pm 4.99 \mathrm{Cb}$ & $72.31 \pm 3.23 \mathrm{Ba}$ \\
\hline & 10 & $29.62 \pm 8.17 \mathrm{Cb}$ & $55.90 \pm 12.69 \mathrm{Bab}$ & $39.41 \pm 11.20 \mathrm{Cb}$ & $72.53 \pm 7.94 \mathrm{Aba}$ \\
\hline & 16 & $9.04 \pm 5.52 \mathrm{Cb}$ & $15.73 \pm 7.26 \mathrm{Cb}$ & $6.68 \pm 4.00 \mathrm{Db}$ & $39.82 \pm 10.42 \mathrm{Ca}$ \\
\hline \multirow[t]{5}{*}{ Middle } & 0 & $98.17 \pm 1.07 \mathrm{Aa}$ & $97.21 \pm 0.94 \mathrm{Aa}$ & $79.03 \pm 3.11 \mathrm{Ab}$ & $87.39 \pm 9.07 \mathrm{Aab}$ \\
\hline & 3 & $68.06 \pm 7.46 \mathrm{Bb}$ & $89.97 \pm 3.49 \mathrm{Aa}$ & $60.94 \pm 5.06 \mathrm{Ab}$ & $80.09 \pm 5.31 \mathrm{ABab}$ \\
\hline & 7 & $15.22 \pm 3.82 \mathrm{Cc}$ & $45.21 \pm 8.39 \mathrm{Bb}$ & $29.84 \pm 5.28 \mathrm{Bbc}$ & $70.78 \pm 5.20 \mathrm{Ba}$ \\
\hline & 10 & $32.27 \pm 9.97 \mathrm{Cb}$ & $54.77 \pm 3.94 \mathrm{Bab}$ & $30.86 \pm 4.25 \mathrm{Bb}$ & $74.62 \pm 2.88 \mathrm{Ba}$ \\
\hline & 16 & $3.70 \pm 3.70 \mathrm{Db}$ & $6.48 \pm 4.38 \mathrm{Cab}$ & $0.00 \pm 0.00 \mathrm{Cb}$ & $24.41 \pm 15.33 \mathrm{Ca}$ \\
\hline
\end{tabular}

Uppercase letters indicate differences between days after application within treatment and layer (column within a layer) whereas lowercase letters indicate differences between treatments on the same day after application (row)

Indoxacarb residual effect

Soybean variety BMX Potencia ${ }^{\circledR}$ (Brasmax Genética Ltd., Passo Fundo, RS, Brazil) was planted in the field in June, 2015 using recommended cultural practices (EMBRAPA 2013), but without insecticide applications. Indoxacarb (30 and $60 \mathrm{~g}$ a.i./ ha for both SC and EC formulations - product label rate) was applied when plants reached R3-R4 growth stage, i.e., pods presented $30 \%$ of final length (Fehr and Caviness 1977). Water was applied on the untreated control. Application of the treatments was performed through a manual costal sprayer coupled to a three-meter bar with six nozzles type XR 11001 VS (TeeJet Technologies, Spraying Systems Co., Glendale Heights, IL, USA). The spraying system was operated with a constant pressure (2.1 bar) and application volume of $200 \mathrm{l} \mathrm{ha}^{-1}$. The experimental design adopted was CRBD (Completely randomized block design) with four replications per treatment. Each plot (replication) measured $3.5 \mathrm{~m} \times 6 \mathrm{~m}$.

After application, soybean leaflets were collected $1 \mathrm{~h}(0 \mathrm{~d}), 3 \mathrm{~d}, 7 \mathrm{~d}$, and $10 \mathrm{~d}$ (days after application). Leaflets were also collected at $16 \mathrm{~d}$, but just for C. includens. For each collection, 128 leaflets were randomly selected from each replication being 64 from the upper third and 64 from the middle layer of the plants, because the insects usually feed on these regions on soybean plants (Moscardi et al.
2012, Stacke et al. 2018). The leaflets were individually transferred into the cells of plastic trays (Advento do Brasil, Diadema, SP, Brazil). For each region of the plant, 32 cells were infested with thirdinstar larvae of $H$. armigera and 32 cells with $C$. includens. The assay was maintained in laboratory conditions $\left(25 \pm 2{ }^{\circ} \mathrm{C}, 46-47 \% \mathrm{RH}, 12: 12 \mathrm{~h}\right.$ [L:D]). For both species, larval mortality (expressed in percentage) and defoliation were accessed. Defoliation was visually evaluated $96 \mathrm{~h}$ after infestation using a $0 \%$ (no injury) to $100 \%$ (all the leaflet fed with some preserved nervures) scale (Fig. 1).

\section{Data analysis}

Mortality obtained from the dose-response bioassays was adjusted to the Probit curve (dose-mortality) to obtain $\mathrm{LC}_{50}$ and $\mathrm{LC}_{99}$ (lethal concentration to kill $50 \%$ and $99 \%$ of the population). The residual effect data (mortality and injury) were submitted to factorial analysis of variance and the means were compared using Tukey test $(P=0.05)$ using PROC GLM. Every mortality datum was transformed into arcsine $\sqrt{x / 100}$. Percent mortality was corrected based on mortality in the untreated control using Abbott's (1925) formula and response curves were compared using Chi-Square (Robertson et al. 2007). The statistical analyses were performed using JMP 12.2.0 or SAS studio (SAS Institute Inc., Cary, NC, USA). 

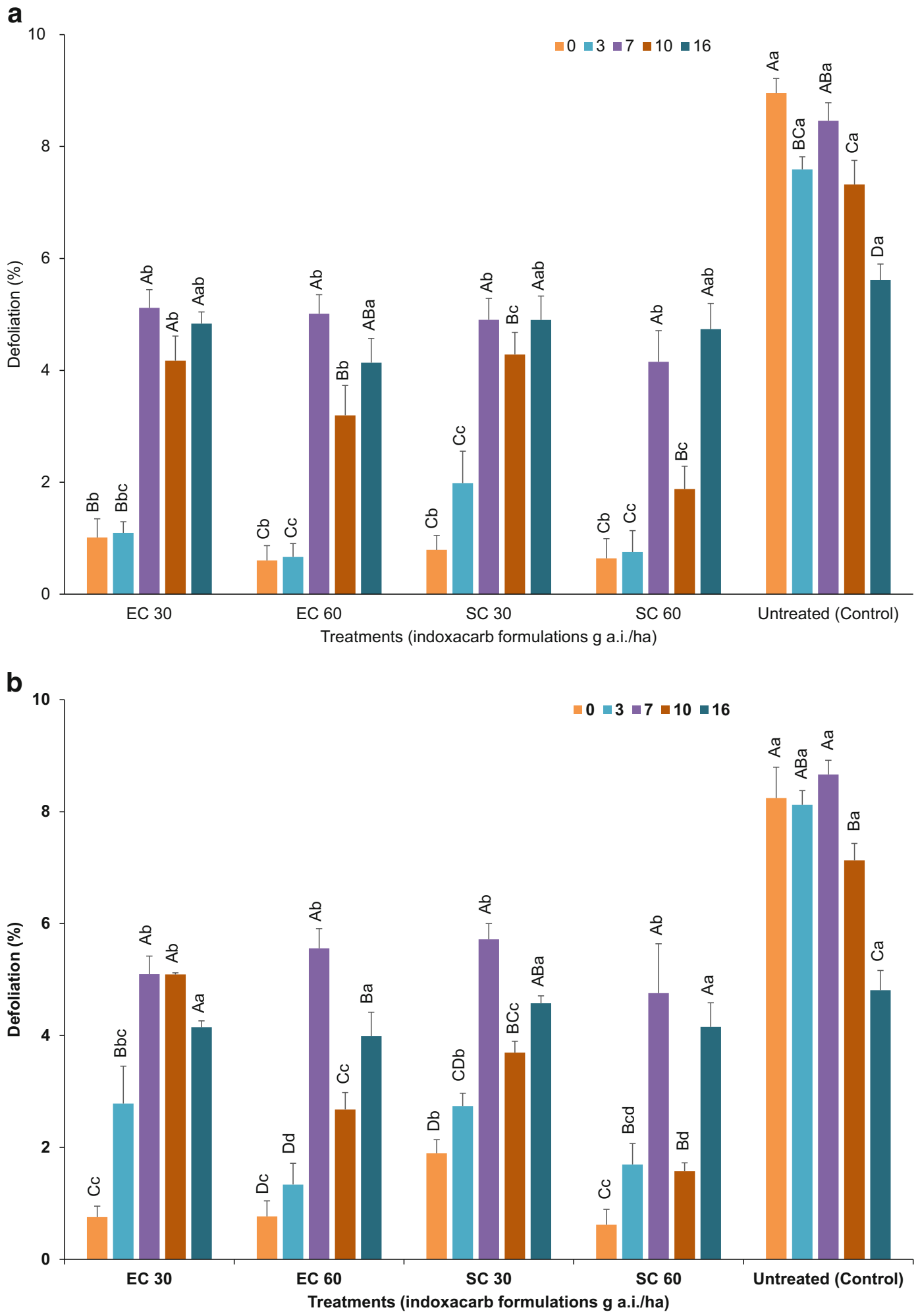

Fig. 2 Defoliation (+ SEM) caused by Chrysodeixis includens in the upper (A) and middle (B) soybean regions at 0 (1 h), 3, 7, 10, and 16 days after application of treatments (Uppercase letters indicate differences between times after application within treatment and lowercase letters indicate differences between treatments on the same time after application) 
Table 3 Mortality $(\% \pm$ SEM) of third-instar Helicoverpa armigera larvae in the upper and middle soybean canopy layers treated with two formulations of indoxacarb (EC - emulsifiable suspension and SC - suspension concentrate)

\begin{tabular}{|c|c|c|c|c|c|}
\hline \multirow[t]{2}{*}{ Canopy Layer } & \multirow[t]{2}{*}{ Days after treatment } & \multicolumn{2}{|c|}{ indoxacarb (15\% EC) } & \multicolumn{2}{|c|}{ indoxacarb (15\% SC) } \\
\hline & & $30 \mathrm{~g}$ a.i./ ha & $60 \mathrm{~g}$ a.i./ ha & $30 \mathrm{~g}$ a.i./ ha & $60 \mathrm{~g}$ a.i./ ha \\
\hline \multirow[t]{4}{*}{ Upper } & 0 & $98.26 \pm 1.02 \mathrm{Aa}$ & $100.00 \pm 0.00 \mathrm{Aa}$ & $96.52 \pm 2.03 \mathrm{Aa}$ & $91.94 \pm 8.07 \mathrm{Aa}$ \\
\hline & 3 & $38.70 \pm 13.98 \mathrm{Bbc}$ & $69.47 \pm 9.01 \mathrm{Ba}$ & $17.02 \pm 7.96 \mathrm{BCc}$ & $52.11 \pm 4.97 \mathrm{Bab}$ \\
\hline & 7 & $15.66 \pm 7.22 \mathrm{BCb}$ & $19.47 \pm 9.49 \mathrm{Cb}$ & $23.39 \pm 5.43 \mathrm{Bab}$ & $48.35 \pm 6.86 \mathrm{Ba}$ \\
\hline & 10 & $1.57 \pm 0.90 \mathrm{Ca}$ & $3.91 \pm 1.97 \mathrm{Ca}$ & $2.35 \pm 0.78 \mathrm{Ca}$ & $3.13 \pm 1.80 \mathrm{Ca}$ \\
\hline \multirow[t]{4}{*}{ Middle } & 0 & $75.38 \pm 5.61 \mathrm{Ab}$ & $100.00 \pm 0.00 \mathrm{Aa}$ & $93.58 \pm 4.12 \mathrm{Aa}$ & $95.63 \pm 3.26 \mathrm{Aa}$ \\
\hline & 3 & $27.88 \pm 9.62 \mathrm{Bb}$ & $72.01 \pm 6.07 \mathrm{Ba}$ & $26.68 \pm 7.25 \mathrm{Bb}$ & $50.30 \pm 15.45 \mathrm{Bab}$ \\
\hline & 7 & $11.07 \pm 6.77 \mathrm{Cb}$ & $37.16 \pm 10.76 \mathrm{Ca}$ & $2.59 \pm 2.59 \mathrm{Cb}$ & $40.74 \pm 11.55 \mathrm{Ba}$ \\
\hline & 10 & $0.81 \pm 0.81 \mathrm{Ca}$ & $0.81 \pm 0.81 \mathrm{Da}$ & $0.81 \pm 0.81 \mathrm{Ca}$ & $0.81 \pm 0.81 \mathrm{Ca}$ \\
\hline
\end{tabular}

Uppercase letters indicate differences between days after application within treatment and layer (column within layer) whereas lowercase letters indicate differences between treatments on the same day after application (row)

\section{Results}

Susceptibility to indoxacarb

The dose response curves of both indoxacarb formulations were similar for $H$. armigera $\left(X^{2}=1.995 ; P=\right.$ $0.1578)$ but not for $C$. includens $\left(X^{2}=6.850 ; P=\right.$ 0.0089) (Table 1). The lethal concentrations $\left(\mathrm{LC}_{50}\right)$ of EC and SC indoxacarb formulations were $0.065(0,028$ 0,147) $\mu \mathrm{g}$ a.i. $\mathrm{ml}^{-1}$ and $0.127(0,046-0,340) \mu \mathrm{g}$ a.i. $\mathrm{ml}^{-1}$ for $C$. includens and $0.113(0,039-0,314) \mu \mathrm{g}$ a.i. $\mathrm{ml}^{-1}$ and $0.111(0,045-0,277) \mu \mathrm{g}$ a.i. $\mathrm{ml}^{-1}$ for $H$. armigera, respectively. Therefore, considering the fiducial limits, both formulations of indoxacarb are similarly toxic to C. includens and $H$. armigera (Table 1).

Indoxacarb residual effect

The mortality caused by indoxacarb to $C$. includens decreased significantly over time $\left(\mathrm{F}_{4,132}=164.52 ; P<\right.$ 0.0001 ) and was the highest just after the application $(1 \mathrm{~h})$ for Avaunt ${ }^{\circledR}$ and up to 3 days after application for Avatar® (Table 2). Consequently, defoliation increased with time and was the lowest just after the application $\left(\mathrm{F}_{4,166}=131.22 ; P<0.0001\right)$ when compared to the untreated control (Fig. 2). Mortality of $C$. includens fed on treated leaflets collected from the upper layer was higher $\left(\mathrm{F}_{1,132}=7.58 ; P=0.0067\right.$; Table 2$)$. Higher doses of both formulations caused higher mortality of C. includens $\left(\mathrm{F}_{1,132}=20.00 ; P<0.0001\right.$ for EC formulation and $\mathrm{F}_{1,132}=61.51 ; P<0.0001$ for SC formulation) and reduced defoliation $\left(\mathrm{F}_{1,166}=14.01 ; P=0.0003\right.$ for $\mathrm{EC}$ formulation and $\mathrm{F}_{1,166}=40.82 ; P<0.0001$ for $\mathrm{SC}$ formulation).

Both formulations of indoxacarb (SC - Avaunt ${ }^{\circledR}$ and EC - Avatar®) were similarly toxic to $H$. armigera $\left(\mathrm{F}_{1,105}=0.21 ; P=0.6494\right)$ leading to likewise reduced injury $\left(\mathrm{F}_{1,132}=2.15 ; P=0.1448\right)$ caused by this insect pest (Table 3; Fig. 3). There was no difference between the upper and middle soybean layers to insect mortality $\left(\mathrm{F}_{1,105}=3.73 ; P=0.0561\right)$ and to foliar injury $\left(\mathrm{F}_{1,132}=\right.$ $1.89 ; P=0.1719)$ in each evaluating time. On the other hand, mortality decreased $\left(\mathrm{F}_{3,105}=242.11 ; P<0.0001\right.$; Table 3) while injury increased $\left(\mathrm{F}_{3,132}=86.92 ; P<\right.$ 0.0001 ; Fig. 3 ) over time. Similar to the results observed for $C$. includens, higher doses of both formulations caused higher mortality of $H$. armigera $\left(\mathrm{F}_{1,105}=\right.$ 24.64; $P<0.0001$ for $\mathrm{SC}$ formulation and $\mathrm{F}_{1,105}=$ 15.07; $P=0.0002$ for EC formulation) and lower defoliation by $H$. armigera $\left(\mathrm{F}_{1,132}=12.11 ; P=0.0007\right.$ for $\mathrm{SC}$ formulation and $\mathrm{F}_{1,132}=4.26 ; P<0.0410$ for $\mathrm{EC}$ formulation).

\section{Discussion}

The two indoxacarb formulations were effective for the control of $H$. armigera and $C$. includens on soybean. The sensibility of the species to indoxacarb was similar. Therefore, the enhancement of indoxacarb formulation (SC - suspension concentrate to EC - emulsifiable concentrate) did not result in increased efficacy. Stacke et al. (2019) evaluated the Brazilian field populations of $C$. includens and noticed up to 6.7-fold resistance 

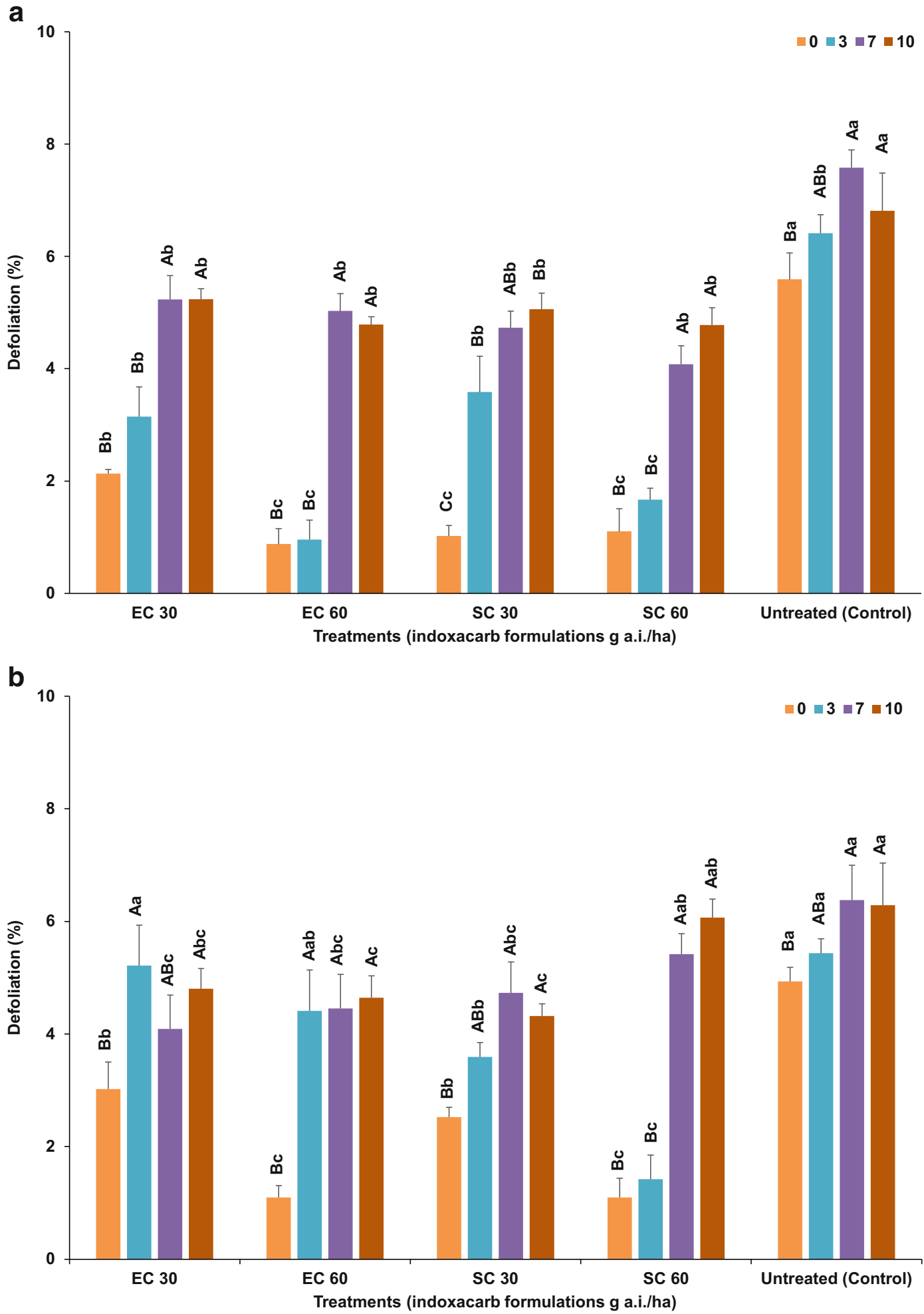

Fig. 3 Defoliation (+ SEM) caused by Helicoverpa armigera in the upper (A) and middle (B) soybean regions at 0 (1 h), 3, 7, and 10 days after application of treatments (Uppercase letters indicate differences between times after application within treatment and lowercase letters indicated differences between treatments on the same time after application) 
ratio to indoxacarb in comparison to a lab susceptible population. The resistance ratio of other nerve action insecticides (e.g., spinetoram, thiodicarb, lambdacyhalothrin) varied from 5.6 to 62.5 . However, similar results for Brazilian field populations of $H$. armigera are not available yet.

In the study on indoxacarb residual effect, high mortality of $H$. armigera was shown on leaflets infested up to $1 \mathrm{~h}$ after indoxacarb application and up to 3 days for C. includens. Similar results were reported by Kuss et al. (2016) using indoxacarb EC formulation for the control of $H$. armigera on soybean. On the other hand, Vinaykumar et al. (2013) reported that indoxacarb controlled $H$. armigera up to 7 days after application on soybean. This difference could be explained by population sensibility to the insecticide indoxacarb (Yang et al. 2013).

Indoxacarb SC and EC formulations presented a good foliar coverage on soybean plants. No mortality difference was found on the leaflets located either on the top or the middle regions of soybean plants. This result is important mainly for C. includens that prefers to feed in leaves located in the middle region of plants (Conte et al. 2014). Failure on efficient foliar coverage should favor survivorship of insects. Consequently, more frequent or repeated applications of insecticides may be necessary for the control (Vivan and Degrande 2011). However, this decision may increase an ecosystem imbalance and costs.

The doses studied were in the range recommended for pest control in different crops. It was expected that higher doses would cause higher mortality and lower defoliation. However, the highest mortality was overall observed on the first day or, at most, 3 days after the application.

The enhanced insecticide indoxacarb EC formulation can be used as one of the strategies within an Integrated Pest Management program for the control of $H$. armigera and $C$. includens on soybean. However, spray cover is essential to assure mortality of these defoliators and particularly of $H$. armigera that feeds on pods within the canopy of plants. Moreover, this study brings information on the susceptibility of indoxacarb to both lepidopteran species. Such information is important as a reference to evaluate the progress and to support Insect Resistance Management (IRM) programs of population resistance development to indoxacarb.

\section{Conclusions}

The new indoxacarb emulsifiable concentrate formulation is as effective as the previous suspension concentrate formulation to control Lepidopterous defoliators. However, residual efficacy is no longer than 3 days after application.

Acknowledgments The authors would like to thank DuPont do Brasil S.A for supporting the research and the field team and interns of Paulinia Experimental Station for technical assistance. We are also grateful to the three anonymous reviewers for their insightful comments.

Availability of data and material Raw data were generated at Paulinia Experimental Station, Dupont do Brasil S. A. Derived data supporting the findings of this study are available from the corresponding author [MGSO] on request.

Authors' contributions MGSO conducted the research; MGSO, RHS, OAF analyzed the data; All authors designed the experiments, analyzed and discussed the results, worked and approved the final manuscript.

Funding the research was funded by DuPont do Brasil S.A.

\section{Compliance with ethical standards}

Conflicts of interest there is no conflict of interest.

Ethics approval the study was carried out in compliance with scientific ethical guidelines.

Consent to participate all authors were involved in the study.

Consent for publication all authors agreed to be part of this publication.

Code availability not applicable.

Open Access This article is licensed under a Creative Commons Attribution 4.0 International License, which permits use, sharing, adaptation, distribution and reproduction in any medium or format, as long as you give appropriate credit to the original author(s) and the source, provide a link to the Creative Commons licence, and indicate if changes were made. The images or other third party material in this article are included in the article's Creative Commons licence, unless indicated otherwise in a credit line to the material. If material is not included in the article's Creative Commons licence and your intended use is not permitted by statutory regulation or exceeds the permitted use, you will need to obtain permission directly from the copyright holder. To view a copy of this licence, visit http://creativecommons.org/licenses/by/4.0/. 


\section{References}

Abbott, W. S. (1925). A method of computing the effectiveness of an insecticide. Journal of Economic Entomology, 18(2), 265267.

Bird, L. J. (2015). Baseline susceptibility of Helicoverpa armigera (Lepidoptera: Noctuidae) to indoxacarb, emamectin benzoate, and chlorantraniliprole in Australia. Journal of Economic Entomology, 108(1), 294-300.

Bueno, R. C. O. F., Parra, J. R. P., Bueno, A. F., Moscardi, F., Di Oliveira, J. R. G., \& Camillo, M. F. (2007). Sem barreira. Cultivar: Grandes Culturas, 93, 12-15.

Conte, O., Oliveira, F. T., Harger, N., \& Corrêa-Ferreira, B. S. (2014). Resultados do manejo integrado de pragas de soja na safra 2013/14 no Paraná. Londrina: Embrapa Soja, 56 p. (Documentos, no. 361). Available at: http://ainfo.cnptia. embrapa.br/digital/bitstream/item/109670/1/Resultados-domanejo-integrado-de-pragas-da-soja-na-safra-2013-14-noParana.pdf

Czepak, C., Albernaz, K. C., Vivan, L. M., Guimarães, H. O., \& Carvalhais, T. (2013). Primeiro registro de ocorrência de Helicoverpa armigera (Hübner) (Lepidoptera: Noctuidae) no Brasil. Pesquisa Agropecuária Tropical, 43, 110-113.

DuPont (2013). DuPont ${ }^{\mathrm{TM}}$ Steward® EC Insecticide: Proven control of beet armyworms, alfalfa weevil larvae, and Egyptian alfalfa weevil larvae in an easy-to-use formulation. Available at: http://www.wickmanchemical.com/wpcontent/uploads/2014/03/2014-Plains-Steward-Sheet.pdf

EMBRAPA - Empresa Brasileira de Pesquisa Agropecuária (2013). Tecnologias de produção de soja - Região central do Brasil 2014. Londrina: Embrapa Soja, 265 p. Available at: https://ainfo.cnptia.embrapa.br/digital/bitstream/item/95489 /1/SP-16-online.pdf.

Fehr, W.R., \& Caviness, C.E. (1977). Stages of soybean development. Spec. Rep. 80. Iowa Agric. Home econ. Exp. Stn., Iowa state Univ., Ames, IA.

Fitt, G. P. (1989). The ecology of Heliothis species in relation to agroecosystems. Annual Review of Entomology, 34, 17-52.

Fitt, G. P., \& Wilson, L. J. (2000). Genetic engineering in IPM: Bt cotton. In G. G. Kennedy \& T. B. Sutton (Eds.), Emerging technologies in integrated Pest management: Concepts, research and implementation (pp. 108-125). St Paul: APS Press.

Forrester, N. W., Cahill, M., Bird, L. J., \& Layland, J. K. (1993). Management of pyrethroid and endosulfan resistance in Helicoverpa armigera (Lepidoptera: Noctuidae) in Australia. Bulletin of Entomological Research, 1, 1-132.

Garcés-Fiallos, F. R. (2011). A ferrugem asiática da soja causada por Phakopsora pachyrhizi Sydow \& Sydow. Revista Ciencia y Tecnologia, 4(2), 45-60.

Gunning, R. V., Moores, G. D., \& Devonshire, A. L. (1996). Insensitive acetylcholinesterase and resistance to thiodicarb in Australian Helicoverpa armigera Hübner (Lepidoptera: Noctuidae). Pesticide Biochemistry and Physiology, 55(1), 21-28.

Gunning, R. V., Moores, G. D., \& Devonshire, A. L. (1997). Esterases and fenvalerate resistance in field population of Helicoverpa punctigera (Lepidoptera: Noctuidae) in Australia. Pesticide Biochemistry and Physiology, 58(2), $155-162$
Herzog, D. C. (1980). Sampling soybean looper on soybean. In M. Kogan \& D. C. Herzog (Eds.), Sampling methods in soybean entomology (pp. 140-168). New York: Springer-Verlag.

ISAAA (2017). Global status of commercialized biotech/GM crops in 2017: Biotech crop adoption surges as economic benefits accumulate in 22 years. ISAAA brief no. 53. Ithaca, NY, USA: ISAAA.

Jones, C. S., \& Bryant, J. L. (2012). Contact toxicity and residual efficacy of indoxacarb against the European earwig (Dermaptera: Forficulidae). Insects, 3(3), 593-600.

Kuss, C. C., Roggia, R. C. R. K., Basso, C. J., Oliveira, M. C. N., Pias, O. H. C., \& Roggia, S. (2016). Controle de Helicoverpa armigera (Lepidoptera: Noctuidae) em soja com inseticidas químicos e biológicos. Pesquisa Agropecuária Brasileira, 51(5), 527-536.

McCann, S. F., Annis, G. D., Shapiro, R., Piotrowski, D. W., Lahm, G. P., Long, J. K., Lee, K. C., Hughes, M. M., Myers, B. J., Griswold, S. M., Reeves, B. M., March, R. W., Sharpe, P. L., Lowder, P., Barnette, W. E., \& Wing, K. D. (2001). The discovery of indoxacarb: Oxadiazines as a new class of pyrazoline-type insecticides. Pest Management Science, 57(2), 153-164.

McKinley, N., Kijima, S., Cook, G., \& Sherrod, D. (2002). Avaunt (Indoxacarb): A new mode of action insecticide for control of several key orchard pests. In Proc. $76^{\text {th }}$ Ann. Western Orchard Pest \& Disease Manag. Conf. (pp 9-11), Portland, Washington state Univ.

Michaud, J. P., \& Grant, A. K. (2003). IPM-compatibility of foliar insecticides for citrus: Indices derived from toxicity to beneficial insects from four orders. Journal of Insect Science, 3(1), $1-10$.

Moral García, F. J. (2006). Analysis of the spatio-temporal distribution of Helicoverpa armigera (Hübner) in a tomato field using a stochastic approach. Biosystems Engineering, 93(3), 253-259.

Moscardi, F., Bueno, A. F., Sosa-Gómez, D. R., Roggia, S., Hoffmann-Campo, C. B., Pomari, A. F., Corso, I. C., \& Yano, S. A. C. (2012). Artrópodes que atacam as folhas da soja. In C. B. Hoffmann-Campo, B. S. Corrêa-Ferreira, \& F. Moscardi (Eds.), Soja: Manejo Integrado de insetos e outros artrópodes-praga (pp. 213-334). Embrapa: Londrina.

Pogue, M. G. (2004). A new synonym of Helicoverpa zea (Boddie) and differentiation of adult males of $H$. zea and H. armigera (Hübner) (Lepidoptera: Noctuidae: Heliothinae). Annals of the Entomological Society of America, 97(6), 1222-1226.

Robertson, J. L., Russel, R. M., Preisler, H. K., \& Savin, N. E. (2007). Bioassays with arthropods (2nd ed.). Boca Raton: CRC Press.

Romeis, J., \& Shanower, T. G. (1996). Arthropod natural enemies of Helicoverpa armigera (Hbn.) in India. Biocontrol Science and Technology, 6(4), 481-508.

Santos, S. R. D., Specht, A., Carneiro, E., Paula-Moraes, S. V. D., \& Casagrande, M. M. (2017). Interseasonal variation of Chrysodeixis includens (Walker, [1858]) (Lepidoptera: Noctuidae) populations in the Brazilian savanna. Revista Brasileira de Entomologia, 61(4), 294-299.

Sosa-Gómez, D. R. (2005). Seletividade de agroquímicos para fungos entomopatogênicos. Londrina: Embrapa. Available at: http://www.cnpso.embrapa.br/download/artigos/seletiv_ fung.pdf. 
Sosa-Gómez, D. R., Delpin, K. E., Moscardi, F., \& Nozaki, M. H. (2003). The impact of fungicides on Nomuraea rileyi (Farlow) Samson epizootics and on populations of Anticarsia gemmatalis Hübner (Lepidoptera: Noctuidae), on soybean. Neotropical Entomology, 32(2), 287-291.

Specht, A., Sosa-Gómez, D. R., Paula-Moraes, S. V., \& Yano, S. A. C. (2013). Morphological and molecular identification of Helicoverpa armigera (Lepidoptera: Noctuidae) and expansion of its occurrence record in Brazil. Pesquisa Agropecuária Brasileira, 48(6), 689-692.

Specht, A., Paula-Moraes, S. V., \& Sosa-Gómez, D. R. (2015). Host plants of Chrysodeixis includens (Walker) (Lepidoptera, Noctuidae, Plusiinae). Revista Brasileira de Entomologia, 59(4), 343-345.

Stacke, R. F., Arnemann, J. A., Rogers, J., Stacke, R. S., Strahl, T. T., Perini, C. R., Dossin, M. F., Pozebon, H., Arruda Cavallin, L., \& Guedes, J. V. (2018). Damage assessment of Helicoverpa armigera (Lepidoptera: Noctuidae) in soybean reproductive stages. Crop Protection, 112, 10-17.

Stacke, R. F., Giacomelli, T., Bronzatto, E. S., Halberstadt, S. A., Garlet, C. G., Muraro, D. S., Guedes, J. V., \& Bernardi, O. (2019). Susceptibility of Brazilian populations of Chrysodeixis includens (Lepidoptera: Noctuidae) to selected insecticides. Journal of Economic Entomology, 112(3), 1378-1387.

Vinaykumar, M. M., Raghvani, K. L., Krishana, N. L., Biradar, A. K., \& Chandrashekar, G. S. (2013). Management of Spodoptera litura (Fabr.) and Helicoverpa armigera (Mats.) in soybean with newer insecticides. International Journal of Green and Herbal Chemistry, 2, 665-674.

Vivan, L. M., \& Degrande, P. E. (2011). Pragas da soja. In F. Siqueri, J. Caju, \& M. Moreira (Eds.), Boletim de Pesquisa de Soja (pp. 239-297). Fundação: Rondonópolis.

Wang, D., Qiu, X., Ren, X., Niu, F., \& Wang, K. (2009). Resistance selection and biochemical characterization of spinosad resistance in Helicoverpa armigera (Hübner) (Lepidoptera: Noctuidae). Pesticide Biochemistry and Physiology, 95(2), 90-94.

Wing, K. D., Schnee, M. E., Sacher, M., \& Connair, M. (1998). A novel oxadiazine insecticide is bioactivated in lepidopteran larvae. Archives of Insect Biochemistry and Physiology, 37(1), 91-103.

Wing, K. D., McCann, S., Andaloro, J. T., \& Salgado, V. L. (2004). Indoxacarb and the sodium channel blocker insecticides: Chemistry, physiology and biology in insects. In L. Gilbert, S. Gill, \& K. Iatrou (Eds.), Comprehensive insect physiology, biochemistry, pharmacology and molecular biology (pp. 31-55). Amsterdam: Elsevier.

Yang, Y., Li, Y., \& Wu, Y. (2013). Current status of insecticide resistance in Helicoverpa armigera after 15 years of $\mathrm{Bt}$ cotton planting in China. Journal of Economic Entomology, 106(1), 375-381.

Publisher's note Springer Nature remains neutral with regard to jurisdictional claims in published maps and institutional affiliations. 